\title{
Collection management of electronic journals in academic libraries: notes on embracing change in an unstable environment
}

\author{
Glenn S. McGuigan
}

As research libraries increasingly assume the role of publisher, a new business model of scholarly publishing is emerging. A recent survey conducted by ARL in late 2007 reveals a high level of activity in this direction:

The survey of ARL members verified that research libraries are rapidly developing publishing services like publication hosting and dissemination, production support, such as peer review workflow management and journal issue compilation, or digitization of back issues. By late 2007, 44\% of the 80 responding ARL libraries reported they were delivering publishing services and another $21 \%$ were currently planning publishing service development.

(Hahn, 2008, 13)

Through inter- and intra-organizational partnerships, research libraries are utilizing open source publishing applications such as DSpace to develop publishing ventures. DSpace, developed jointly by MIT Libraries and Hewlett Packard Labs, allows libraries to "capture, store, index, and redistribute" scholarly content within an institutional repository (DSpace, 2005). With the availability of such tools, this trend will dramatically impact the scholarly publishing system and the management of electronic journals. Clearly, change is in the air.

How did we arrive at the point in which the research library is transforming from journal content middleman, serving as an intermediary between the publishers and consumers, into the role of publisher? Librarians and administrators within the academic library community lament the sad state of affairs where journal prices escalate every year at double digit levels. While library budgets are shrinking as a result of the higher education funding crisis, the monopolistic academic journal publishing market continues to demand higher and higher prices every year for new bundled packages of electronic and paper journals. Therefore, as librarians try to keep their budgetary heads above water, they continue the annual exercise of cutting journal subscriptions and continue to shift funds from monographic budgets to periodicals budgets to cover the inevitable shortfalls. It is often the

\section{Glenn S. McGuigan}

Glenn S. McGuigan is Business and Public Administration Reference Librarian at Penn State Harrisburg, USA.

Email: gxm22@psu.edu 
journals of smaller publishers and scholarly societies that are cut, since those large bundled titles often cannot be cut without violating a license agreement.

Considering these points, this development, as a reaction to the current scholarly publishing environment, may serve as a new, viable paradigm. At the very least, this undertaking may impel large scholarly publishers to rethink their current business model. The development of publishing initiatives within academic libraries is a sign of the development of necessary strategies to address the scholarly publishing crisis.

Library collection management exists in an unprecedented environment of change. A ground-breaking article, published almost a decade ago, provides a framework to discuss the internal and external factors impacting scholarly publishing. First published as an Association of Research Libraries (ARL) report in 1999 and later as a journal article in the January 2000 edition of Library Resources and Technical Services (LRTS), "The Changing Nature of Collection Management in Research Libraries" by Branin, Groen, and Thorin is a must-read for all academic and special librarians. This work provides a history of collection management over time and addresses the following points: information overload (including the rapid growth of research library collections through the 20th century); the shift from traditional "collection development" or acquisitions to "collection management" (as an integrated activity encompassing "policy, planning, analysis, and cooperative activities"); the failure from the 1950's to the 1980's of cooperative collection development; fiscal constraint (as in the reduced budgets of many academic libraries in the 1980s); and the development of digital information systems. The key concept within this environment is change:

The new procedures that made sense for managing collections only thirty years ago have been turned topsy-turvy by changes in higher education and publishing, by the emergence of the new digital information system, and by a weak library economy.

(Branin et al., 2000, 30).

This quote relates the importance of various forces impacting us within academic libraries, such as reduced budgets, enhanced technology, and consolidation of the publishing industry. The current period has been referred to as "a new and uncharted environment" by the authors, and this clearly is the case, considering that there is no equivalent to the radical changes that we are currently experiencing.

The transition to electronic delivery influences how academic libraries fulfill their mission of delivering scholarly resources and services to their constituents. In a chapter entitled "Business Libraries: Changing Collections, Services and Roles" by McGinn, published in the The Basic Business Library: Core Resources edited by Karp, the author points out the specific changes that impact resources in academic libraries. While addressing specifically collections in business (or special) libraries, the major points that McGinn discusses could apply to all academic library collections and include the following: 
- Reengineering of business libraries: Topics include outsourcing, changes in priorities and services, especially relating to electronic or online information.

- Changes in the information seeking behavior of users: While patrons are increasing using off-site access and engaging in the manipulation of electronic information, she contends that there still exists the necessity of mediated searching, and continuing purchase of necessary print resources.

- Changes in the format of business information: There is movement towards full digital libraries. However libraries face the dichotomy between proprietary databases and the abundance of free business information Web sites.

- Changes in collection development strategies and collection access: New cataloging and classification systems are in development, in which there is a merger between catalogs and indexes, full text databases, and document delivery options. Also there is the transformation of library space from "physical" to "virtual"; industry portals; and the use of intranets (corporate).

McGinn then sums up the changes and their effects upon the mission of academic business libraries:

The ability to deliver business information in an efficient, reliable, customized, and user-friendly manner has always been a goal of business libraries; the changes brought about by twenty-first century technology have made this goal more attainable, at the same time as the array of choices has become more complex.

(McGinn, 2002, 122).

Also the chapter "Acquisitions and Collection Development in Business Libraries" by Stephen S. Crandall and Toni P. Olshan in the same work, The Basic Business Library: Core Resources edited by Karp (2002), offers significant insight into the state of academic collection management, while also focusing on business resources. The authors address four main points regarding the operating environment:

- The Web has altered the process of acquisitions and collection development.

- The trend of delivering access to electronic resources impacts the relationship between libraries and publishers.

- Creation of library consortia has been a response to these changes so libraries can insure more favorable pricing than they could on their own.

- New questions that have never existed before are now being asked: Which consortium with which contract offers the best price? Will contract provide for stable, long-term access to a product, being considered, or does the library lose all access when the subscription ends?

A noteworthy point in this discussion is that while collections are changing as a result of the electronic revolution, and the roles of librarians are changing in how they do their jobs, the institutions of academic libraries are still based on the same notions as before, and the relationships with publishers have not changed to 
reflect these changes. Tension exists between the immature digital information system and the traditional scholarly publishing environment in terms of subscriptions and storage.

In summary, the major developments facing collection management of journals in academic and special libraries concern change. There are changes in the availability of technology, changes due to reduced or constrained library budgets, and changes being brought about by the information seeking behavior of users. As a result of the electronic transformation in terms of licensing, academic libraries have enhanced access but diminished control. Regarding funding, academic libraries struggle to provide access to the same scholarly resources they could in the past. New models, such as academic libraries taking on the role of publisher, as revealed in the ARL survey, are increasing. It is still not clear how the major commercial publishers will react to these initiatives, although some are exploring alternative business models. There is a chance that the large commercial publishers themselves could facilitate needed reforms, especially since they possess the economies of scale and the expertise in the field. Rather than continuing with aggressive pricing approaches, publishers may seize the opportunity to serve as agents of change, with long-term strategies, to reduce the prices of their journals and/or embrace Open Access models to guarantee the survival of many long-running journal titles. During this tumultuous period, there are great opportunities for the transformation of scholarly communication that will strongly impact academic libraries and the scholarly communities that these libraries serve.

\section{References}

Branin, J.J., Groen, F.K., and Thorin, S.E. (2000) The changing nature of collection management in research libraries. Library Resources \& Technical Services. Vol. 44, no. 1, p. 23-32.

Crandall, S.S. and Olshan, T.P. (2002) Acquisitions and collection development in business libraries. In: Karp, R. S. (ed.) The basic business library: core resources. $4^{\text {th }}$ Ed. Westport, CT: Greenwood Press. 217-230.

DSpace.Org (2008) URL: http://www.dspace.org [accessed 29.4.08].

Hahn, K.L. (2008) Research library publishing services: new options for university publishing. Washington, DC: Association of Research Libraries.

Karp, R. S. (ed.) (2002) The basic business library: core resources. $4^{\text {th }} \mathrm{Ed}$. Westport, CT: Greenwood Press.

McGinn (2002) Business libraries: changing collections, services and roles. In:

Karp, R. S. (ed.) The basic business library: core resources. $4^{\text {th }}$ Ed. Westport, CT: Greenwood Press. 109-126. 